Назарій Вербин, кандидат педагогічних наук

Навчально-науковий інститут фізичної культури та спортивно-оздоровчих технологій Національного університету оборони України імені Івана Черняховського, м. Київ

ORCID ID 0000-0002-1977-3471

Вадим Шемчук, кандидат педагогічних наук

Навчально-науковий інститут фізичної культури та спортивно-оздоровчих технологій Національного університету оборони України імені Івана Черняховського, м. Київ

ORCID ID 0000-0001-8873-0443

Анна Саїнчук, кандидат наук з фізичного виховання і спорту

Навчально-науковий інститут фізичної культури та спортивно-оздоровчих технологій Національного університету оборони України імені Івана Черняховського, м. Київ

ORCID ID 0000-0002-3472-829X

Тетьяна Терещенко, кандидат медичних наук

Навчально-науковий інститут фізичної культури та спортивно-оздоровчих технологій Національного університету оборони України імені Івана Черняховського, м. Київ

ORCID ID 0000-0002-9948-0846

DOI: $10.33099 / 2617-1775 / 2020-02 / 49-58$

\title{
ОСОБЛИВОСТІ ПІДГОТОВКИ МАЙБУТНІХ ФАХІВЦІВ ФІЗИЧНОЇ ПІДГОТОВКИ І СПОРТУ ДО РОБОТИ З ВІЙСЬКОВОСЛУЖБОВЦЯМИ З ОБМЕЖЕНИМИ ФІЗИЧНИМИ МОЖЛИВОСТЯМИ
}

В статті розглянуто проблему підготовки майбутніх фахівців фізичної підготовки $i$ спорту до роботи з військовослужбовцями з обмеженими фізичними можливостями. 3'ясовано, щзо вирімальну роль для реабілітації військовослужбовців з особливими потребами відіграє рухова активність. Однак, аналіз науково-методичної літератури та військової практики засвідчив, щзо питанню їх підготовки не приділено достатньої уваги.

Здійснено аналіз програми підготовки бакалаврів з дисиипліни “Фізична реабілітація та адаптивне фізичне виховання”, яка розроблена відповідно до стандарту вищої освіти за спеціальністю “Фізична культура і спорт” та враховує психолого-педагогічні відмінності у діяльності професіонала в галузі адаптивної фізичної культури. Зазначена програма складається з трьох блоків: теоретичного, методичного та практичного та дозволяє на належному рівні підготувати майбутніх фахівців фізичної підготовки і спорту до роботи $з$ військовослужбовиями з обмеженими фізичними можливостями.

Ключові слова: адаптивне фізичне виховання; майбутні фахівиі з фізичної підготовки $i$ спорту; підготовка; обмежені фізичні можливості; військовослужбовиі; нозології.

Постановка проблеми. Антитерористична операція Збройних Сил України, а в подальшому Операція об’єднаних сил, що тривають вже сьомий 
рік поспіль призвела до значних бойових втрат серед військовослужбовців різних видів та родів військ, які віддавали та продовжують віддавати своє саме цінне - життя, захищаючи територіальну цілісність та недоторканість своєї Батьківщини. Значна кількість наших героїв отримали поранення, контузії та втратили ті чи інші функціональні спроможності (погіршення зору та слуху, ампутація, видалення уражених органів). Всі ці чинники нерідко закінчується для військовослужбовців розвитком несприятливих наслідків (медичних, психологічних, соціальних), що призводять до тривалої чи незворотної інвалідизації.

Керівництво держави, Міністерства оборони України та Збройних Сил України робить все для даної категорії військовослужбовців, щоб вони залишались повноцінними членами нашого суспільства та своїх військових колективів зокрема. Так, за окремим рішенням Міністра оборони України значна кількість осіб з обмеженими функціональними можливостями має можливість продовжувати військову службу на визначених посадах, які не вимагають високих фізичних навантажень та складних локомоторних рухів. Це посади у військових комісаріатах, науково-дослідних установах, навчальних закладах, органах військового управління. Також, військовослужбовців, що віднесенні до зазначеної категорії мають можливість навчатися у вищих військових навчальних закладах та військових навчальних підрозділів закладів вищої освіти.

Відомий факт, що вирішальну роль для реабілітації військовослужбовців 3 особливими потребами відіграє рухова активність. Зусилля фахівців медичної служби та фізичної підготовки i спорту спрямовані на пошук шляхів оптимального використання засобів фізичної підготовки для досягнення необхідного рівня працездатності, зміцнення здоров'я та адаптації осіб 3 обмеженими функціональними можливостями.

Саме тому постає нагальне питання щодо готовності фахівців фізичної підготовки і спорту вирішувати питання соціалізації військовослужбовців 3 обмеженими функціональними можливостями, а саме до їх підготовленості як у теоретичних питаннях, так і в практичних уміннях та навичках роботи з даною категорією військовослужбовців. Так як проста імпровізація методичної допомоги з рухової активності може привести до незворотних наслідків у стані здоров'я військовослужбовців.

Аналіз останніх досліджень i публікацій. Проблеми адаптивного фізичного виховання (далі - АФВ) тривалий час перебувають у полі зору досліджень як вітчизняних науковців, так i іноземних фахівців. Так, Н. Байкіною, Я. Крет, О. Поддуєвою було розроблено методику спеціальної корекційно-розвивальної роботи для розвитку психомоторики в глухих [1], Р. Чудною обгрунтовано структуру та зміст навчальної дисципліни “Адаптивне фізичне виховання" в системі вищої фізкультурної освіти [2], Н. Вербином та С. Жембровським роброблена методика контролю фізичної підготовленості офіцерів з фізичними вадами [3]. 
За останнє десятиліття значну увагу науковці приділяли дослідженням підготовки фахівців для галузі адаптивного фізичного виховання. Так, О. Томащук, О. Хриплюк досліджено сутність проблеми професійної підготовки майбутніх фахівців з адаптивного фізичного виховання до роботи в центрах інваспорту [4]. Науковцями Є. Імасом, О. Борисовою, I. Когут досліджено особливості змісту професійної підготовки фахівців сфери фізичної культури та спорту щодо роботи 3 особами 3 інвалідністю [5]. Вчений Р. Карпюк визначив теоретичні і методичні засади професійної підготовки майбутніх фахівців з адаптивного фізичного виховання у вищих навчальних закладах [6].

Аналіз підготовки майбутніх фахівців з адаптивного фізичного виховання в зарубіжних країнах засвідчив, що там також приділяється значна увага різним аспектам АФВ. Так, програма Університету штату Огайо (США) спрямована на підготовку таких фахівців, як Physical Education Pedagogy, Adapted Physical Education and Physical Education Teacher Education (педагог фізичної культури, фахівець 3 адаптивного фізичного виховання й викладач фізичної культури). В Університеті Virginia (Канада) на факультеті кінезіології та оздоровчих технологій основна увага приділяється формуванню знань студентів щодо ролі адаптивної фізичної активності в оздоровленні інвалідів; у Латиській академії спортивної освіти розпочалася підготовка фахівців з Adapted Physical Education адаптивного фізичного виховання; Палацький університет Оломоуц (Чехія) здійснює підготовку фахівців з адаптивної фізичної активності (3-річний термін навчання на бакалавра та 5-річний для отримання ступеня магістра) [7].

Однак, аналіз науково-методичної літератури підтвердив твердження про те, що питанню підготовки майбутніх фахівців фізичної підготовки і спорту до роботи 3 військовослужбовцями з обмеженими фізичними можливостями не приділено достатньої уваги.

Саме це визначило мету нашого дослідження, яка полягає у з'ясування основних аспектів підготовки майбутніх фахівців фізичної підготовки і спорту до роботи з військовослужбовцями з обмеженими фізичними можливостями.

Виклад основного матеріалу дослідження. Сучасне АФВ в Україні 3 кожним роком все більше набуває юридичне забезпечення в державній системі реабілітації інвалідів, які визначені Законом України "Про основи соціального захисту інвалідів". Також, у Законі України «Про фізичну культуру і спорт» наголошується на питанні фізичної культури інвалідів: “...cт.13. Фізкультурнооздоровча і спортивна діяльність серед інвалідів. Заняття фізичною культурою і спортом інвалідів $є$ складовою частиною їхнього дозвілля, фізичної реабілітації та соціально-трудової адаптації” [8].

Головною особливістю АФВ $є$ те, що суб'єктом педагогічного впливу $є$ особа $з$ суто індивідуальними властивостями, що зумовлені патологічними порушеннями у розвитку (сенсорними, руховими, інтелектуальними, поєднаними формами), що зазвичай негативно відображається на локомоторній функції, фізичному розвитку та підготовленості, можливості до навчання 
рухам, роздільної здатності психомоторних проявів, що, безсумнівно, вимагає індивідуальної корекції педагогічних впливів [9, с. 45].

Саме тому першочергове місце займає фахівець 3 АФВ, професіоналізм якого має такі складові: професіоналізм діяльності й особистості майбутнього фахівця з адаптивного фізичного виховання; нормативну регуляцію; мотивацію на саморозвиток і професійні досягнення; рефлексивну самоорганізацію; творчий інноваційний потенціал особистості майбутнього фахівця 3 адаптивного фізичного виховання; належний рівень здоров'я, фізичних i психічних кондицій у майбутнього фахівця з адаптивного фізичного виховання [10].

Дослідниця Р. Чудна у свою чергу зазначає, що великого значення під час роботи з особами, що мають обмежені фізичні можливості, набуває особистісний компонент готовності педагога, до яких вона відносить такі якості: сумлінність, емоційну стабільність і психологічну стійкість, твердість, терпіння, уміння задовольнятися невеликими успіхами, стриманість у прояві емоцій, у рухах i поведінці. Також великий виховний вплив мають зразкова поведінка, справедливе неупереджене ставлення до усіх членів колективу i абсолютно неприпустимим $\epsilon$ висміювання будь-чиїх слабкостей 3 боку викладача. I найголовнішим аспектом в адаптивній фізичній культурі, як зазначає вчена, $\epsilon$ важлив похвала, але слід пам'ятати, що вона повинна бути завжди щирою та своєчасною, краще хвалити дію, вчинок, ніж особистість [2].

У Збройних Силах України АФВ військовослужбовців 3 обмеженими фізичними можливостями здійснюється фахівцями фізичної підготовки i спорту, а саме: викладачами фізичного виховання, спеціальної фізичної підготовки i спорту у ВВНЗ та начальниками фізичної підготовки спорту військових частин.

Підготовка фахівців 3 фізичної підготовки і спорту здійснюється в навчально-науковому інституті фізичної культури та спортивно-оздоровчих технологій Національного університету оборони України імені Івана Черняховського за спеціальністю “Фізична культура і спорт” спеціалізацією “Фізичне виховання і спорт у Збройних Силах" для Збройних Сил України та інших військових формувань України, утворених відповідно до законів України.

При вступі до вузу курсантам пропонується як вибіркова дисципліна “Фізична реабілітація та адаптивне фізичне виховання”, яка вивчається у 6 та 7 семестрах. Курсантами відпрацьовуються 7 тем, 3 яких 4 теми 3 розділу фізичної реабілітації та 3 - 3 адаптивного фізичного виховання: “Загальнотеоретичні основи адаптивного фізичного виховання”, "Адаптивне фізичне виховання при різних нозологіях і вадах" та "Адаптивний спорт". Обсяг навчальної дисципліни складає 210 годин / 7 кредитів СКТС, із них: під керівництвом викладача - 140 годин (лекцій - 48 год., семінарських (групових) занять - 46 год., практичних занять - 46 год., диференційованих заліків - 2 год., екзаменів - 2 год.); на самостійну роботу - 70 годин. Розділ АФВ вивчається після фізичної реабілітації у 7 семестрі, обсяг якої складає 90 годин / 3 кредитів 
ЄКТС, із них: під керівництвом викладача - 60 годин (лекцій - 20 год., семінарських (групових) занять - 20 год., практичних занять - 18 год., екзамен -2 год.); на самостійну роботу - 30 годин.

Підготовка фахівців фізичної підготовки і спорту до роботи з особами 3 обмеженими фізичними можливостями мають кардинальні відмінності зі здоровими військовослужбовцями. Слід погодитись 3 твердженнями дослідниць Н. Москаленко та А. Ковтун, які у роботі над сучасними підходами до викладання навчальної дисципліни “Адаптивне фізичне виховання" представили деякі психолого-педагогічні відмінності у діяльності професіонала в галузі адаптивної фізичної культури, головними з яких є такі:

суб'єктом педагогічної діяльності галузі адаптивної фізичної культури $є$ особа з обмеженими психофізичними можливостями;

професійна діяльність у сфері адаптивної фізичної культури значною мірою пов'язана із наданням допомоги цій категорії осіб у формуванні позитивної самооцінки на основі створення для них ситуації успіху в руховій діяльності;

для діяльності фахівця з адаптивної фізичної культури характерний більш високий ступінь психічної напруженості порівняно $з$ діяльністю професіонала 3 фізичної культури;

добір і використання педагогом з адаптивної фізичної культури фізичних вправ у процесі навчання техніки рухових дій, прийомів фізичної допомоги i страховки з урахуванням реальних можливостей учасників групи залежно від ступеня вираження дефекту (фізичного, сенсорного, психічного) є складнішим, ніж у фізичній культурі, завданням;

фахівець 3 адаптивної фізичної культури обов'язково повинен реалізовувати індивідуальний підхід;

заохочення зусиль і старань осіб з обмеженими фізичними можливостями не меншою, а навіть більшою мірою, ніж їх реальних успіхів, обумовлено тим, що позитивної динаміки протягом тривалого часу може й не бути [11].

Саме тому, нами обрано систему підготовки, що складається 3 трьох блоків: теоретичного, методичного та практичного. Так, в теоретичному блоці курсанти засвоюють теоретичний матеріал лекцій та групових занять щодо загальних основ адаптивного фізичного виховання, основних засобів та методів адаптивного фізичного виховання. Важливим аспектом $\epsilon$ розбір форми адаптивного фізичного виховання, на яких фахівці фізичної підготовки і спорту здійснюють вплив на осіб з обмеженими фізичними можливостями. Головним завданням теоретичного блоку $\epsilon$ ознайомлення курсантів 3 адаптивним фізичним вихованням при різних нозологіях (глухота, порушення опорнорухового апарату та ураження спинного мозку).

32014 року як розпочалась військова агресія з боку Російської Федерації, значної популярності набули Ігри нескорених (Invictus Games) - міжнародні спортивні змагання в паралімпійському стилі, в яких українські спортсменивійськовослужбовці стають чемпіонами та призерами в різних програмах 
змагань. Саме тому, в теоретичному блоці висвітлюються питання пов’язанні 3 адаптивним спортом та його розвитком.

Методичний блок включає в себе методичну підготовку майбутніх фахівців фізичної підготовки i спорту щодо планування, підготовки та проведення занять 3 особами 3 обмеженими фізичними можливостями. На навчально-методичних заняттях вони набувають навички 3 проведення підготовчої, основної та заключної частини заняття чи тренування, створення єдиного підходу застосування засобів i методів адаптивного фізичного виховання, а також навчання вправам, прийомам і діям. Особливостями даного блоку $є$ те, що кожен курсант відпрацьовує свої методичні навички як у ролі керівника заняття, так i у ролі особи з обмеженими можливостями різних нозологічних груп.

Практична підготовка майбутніх фахівців фізичної підготовки і спорту здійснюється під час розв'язання на семінарських заняттях проблемних практичних завдань з оцінки і аналізу стану здоров'я і фізичного розвитку осіб різних нозологічних груп, розробки для них програм рухової активності, що базуються на основних закономірностях розвитку фізичних якостей адаптивного фізичного виховання, залежності розвитку фізичних здібностей від рухових режимів та етапність розвитку фізичних якостей. Також визначають обсяг рухових можливостей та тестування під час різних нозологій, розробляють методичні вказівки з адаптивного фізичного виховання для осіб даної категорії.

Після вивчення дисципліни практична складова дисципліни відпрацьовується на військовому стажуванні, яке курсанти проходять наприкінці четвертого року навчання у військових частинах на посадах начальників фізичної підготовки і спорту. Одним із завдань стажування $\epsilon$ розробка програми з адаптивного фізичного виховання та проведення занять у військових частинах 3 військовослужбовцями 3 обмеженими фізичними можливостями.

Таким чином узагальнюючи результати досліджень з проблеми підготовки майбутніх фахівців фізичної підготовки i спорту до роботи 3 військовослужбовцями 3 обмеженими фізичними можливостями в науковій літературі та військовій практиці, ми дійшли висновку, що процес їх підготовки ускладняється тим, що адаптивне фізичне виховання в системі Збройних Сил України $є$ відносно новим явищем, актуальність якого спостерігається останніх 4-5 років. Саме тому, підготовка майбутніх фахівців фізичної підготовки $\mathrm{i}$ спорту до роботи 3 даною категорією військовослужбовців $є$ досить актуальною проблемою на сучасному етапі розвитку фізичної підготовки військовослужбовців, тому що сьогодні захисники нашої Батьківщини потребують підтримку не тільки у соціальному та психологічному відношенні, а також і у руховій активності під час занять адаптивного фізичного виховання і спорту.

Напрями подальших досліджень с обгрунтування програми адаптивного фізичного виховання військовослужбовців з урахуванням різних нозологій та 
займаних посад у військових комісаріатах, науково-дослідних установах, навчальних закладах, органах військового управління.

\section{ЛІТЕРАТУРА}

1. Байкіна Н. Діагностика i корекція психомоторики в глухих дітей / Н. Байкіна, Я. Крет, О. Поддуєва // Нова педагогічна думка. - 2013. - № 4. - С. 50-54.

2. Чудна Р. В. Обгрунтування структури та змісту навчальної дисципліни “Адаптивне фізичне виховання" в системі вищої фізкультурної освіти: дис.... канд. наук з фіз.вих. i спорту: 24.00.02 / Чудна Рада Валентинівна - К.: НУФВіСУ, 2003. - 195 с.

3. Вербин Н. Б. Методика контролю фізичної підготовки майбутніх магістрів військового управління групи адаптивного фізичного виховання / Н.БВербин, С. М. Жембровський // Наукові записки. - 2015. - Вип. CXXVIII (128). - C. 44-53.

4. Томащук О. Сутність проблеми професійної підготовки майбутніх фахівців 3 адаптивного фізичного виховання до роботи в центрах інваспорту / О. Томащук, О. Хриплюк // Фізичне виховання, спорт і культура здоров’я у сучасному суспільстві. - 2012. - № 2 (18). C. 88-90.

5. Імас Є. Особливості змісту професійної підготовки фахівців сфери фізичної культури та спорту щодо роботи з особами з інвалідністю / Є. Імас, О. Борисова, І. Когут // Фізичне виховання, спорт і культура здоров’я у сучасному суспільстві. - 2016. - № 3 (35). - С. 17-25.

6. Карпюк Р. П. Теоретичні і методичні засади професійної підготовки майбутніх фахівців з адаптивного фізичного виховання у вищих навчальних закладах : автореферат дис. ... докт. пед. наук : 13.00.04 / Р. П. Карпюк; Нац пед. ун-т ім. М. П. Драгоманова. - Київ, 2010. $-40 \mathrm{c}$.

7. Карпюк Р. П. Аналіз зарубіжних навчальних планів підготовки фахівців для галузі адаптивної фізичної культури. URL : https://www.sportpedagogy.org.ua/html/journal/200811/08krppts.pdf (дата звернення 28.09.2020).

8. Закон України : Про фізичну культуру і спорт. Постанова Верховної Ради України №3809 - ХІІ від 24 грудня 1993p. - К., 1994.

9. Евсеев С. П. Адаптивная физическая культура: учебн. пособие / С. П. Евсеев, Л. В. Шапкова - М.: Советский спорт, 2000. - 240 с.

10. Карпюк Р. П. Складові професіоналізму фахівця 3 адаптивного фізичного виховання. URL : https://www.sportpedagogy.org.ua/html/journal/2009-06/09krpape.pdf (дата звернення 28.09.2020).

11. Москаленко Н. Сучасні підходи до викладання навчальної дисципліни “Адаптивне фізичне виховання” / Н. Москаленко, А. Ковтун // Спортивний вісник Придніпров’я. - 2015. - № 2. - C. 119-123.

12. Шемчук В.А. Структурно-функціональна модель використання технічних засобів навчання для підтримання фізичної працездатності здобувачів вищої освіти в умовах самоізоляції. / В.А. Шемчук, В.П. Семененко, С.В. Трачук, Г.С. Храпач, С.П. Ляхович // Запоріжжя: КПУ, "Педагогіка формування творчої особистості у вищій і загальноосвітній школах”, 2020 р., №71, Т.2. - С.249-255.

\section{REFERENCES}

1. Baikina N. Diahnostyka i korektsiia psykhomotoryky v hlukhykh ditei / N. Baikina, Ya. Kret, O. Podduieva // Nova pedahohichna dumka. - 2013. - № 4. - P. 50-54.

2. Chudna R. V. Obgruntuvannia struktury ta zmistu navchalnoi dystsypliny "Adaptyvne fizychne vykhovannia" $\mathrm{v}$ systemi vyshchoi fizkulturnoi osvity: dys... kand. nauk z fiz.vykh. i sportu: 24.00.02 / Chudna Rada Valentynivna - K.: NUFViSU, 2003. - 195 p.

3. Verbyn N. B. Metodyka kontroliu fizychnoi pidhotovky maibutnikh mahistriv viiskovoho upravlinnia hrupy adaptyvnoho fizychnoho vykhovannia / N. B Verbyn, S. M. Zhembrovskyi // Naukovi zapysky. - 2015. - Vyp. CXXVIII (128). - P. 44-53. 
4. Tomashchuk O. Sutnist problemy profesiinoi pidhotovky maibutnikh fakhivtsiv z adaptyvnoho fizychnoho vykhovannia do roboty $\mathrm{v}$ tsentrakh invasportu / O. Tomashchuk, O. Khrypliuk // Fizychne vykhovannia, sport i kultura zdorovia u suchasnomu suspilstvi. - 2012. № 2 (18). - P. 88-90.

5. Imas Ye. Osoblyvosti zmistu profesiinoi pidhotovky fakhivtsiv sfery fizychnoi kultury ta sportu shchodo roboty z osobamy z invalidnistiu / Ye. Imas, O. Borysova, I. Kohut // Fizychne vykhovannia, sport i kultura zdorovia u suchasnomu suspilstvi. - 2016. - № 3 (35). - P. 17-25.

6. Karpiuk R. P. Teoretychni i metodychni zasady profesiinoi pidhotovky maibutnikh fakhivtsiv $\mathrm{z}$ adaptyvnoho fizychnoho vykhovannia u vyshchykh navchalnykh zakladakh: avtoreferat dys. ... dokt. ped. nauk : 13.00 .04 / R. P. Karpiuk; Nats ped. un-t im. M. P. Drahomanova. - Kyiv, 2010. -40 p.

7. Karpiuk R. P. Analiz zarubizhnykh navchalnykh planiv pidhotovky fakhivtsiv dlia haluzi adaptyvnoi fizychnoi kultury. URL: https://www.sportpedagogy.org.ua/html/journal/2008-11/08krppts.pdf (data zvernennia 28.09.2020).

8. Zakon Ukrainy : Pro fizychnu kulturu i sport. Postanova Verkhovnoi Rady Ukrainy №3809 - XII vid 24 hrudnia 1993 r. - K., 1994.

9. Evseev S. P. Adaptyvnaia fyzycheskaia kultura: [uchebn. posobye] / S. P. Evseev, L. V. Shapkova - M.: Sovetskyi sport, 2000. - 240 p.

10. Karpiuk R. P. Skladovi profesionalizmu fakhivtsia $\mathrm{z}$ adaptyvnoho fizychnoho vykhovannia. URL : https://www.sportpedagogy.org.ua/html/journal/2009-06/09krpape.pdf (data zvernennia 28.09.2020).

11. Moskalenko N. Suchasni pidkhody do vykladannia navchalnoi dystsypliny "Adaptyvne fizychne vykhovannia" / N. Moskalenko, A. Kovtun // Sportyvnyi visnyk Prydniprovia. - 2015. № 2. - P. 119-123.

12. Shemchuk V.A. Strukturno-funktsionalna model vykorystannia tekhnichnykh zasobiv navchannia dlia pidtrymannia fizychnoi pratsezdatnosti zdobuvachiv vyshchoi osvity $\mathrm{v}$ umovakh samoizoliatsii. / V.A. Shemchuk, V.P. Cemenenko, S.V. Trachuk, G.S. Hrapach, S.P. Lyakhovych // Zaporizhia: KPU, "Pedahohika formuvannia tvorchoi osobystosti u vyshchii i zahalnoosvitnii shkolakh”, 2020, №71, T.2. - S.249-255.

\section{PЕЗЮМЕ}

\section{Назарий Вербин,}

кандидат педагогических наук

Учебно-научный институт физической культуры и спортивно-оздоровительных технологий

Национального университета обороны Украины имени Ивана Черняховского

Вадим Шемчук, кандидат педагогических наук

Учебно-научный институт физической культуры и спортивно-оздоровительных технологий

Национального университета обороны Украины имени Ивана Черняховского

Анна Саинчук,

кандидат наук с физического воспитания и спорта

Учебно-научный институт физической культуры и спортивно-оздоровительных технологий

Национального университета обороны Украины имени Ивана Черняховского 
Татьяна Терещенко, кандидат медицинских наук

Учебно-научный институт физической культуры и спортивно-оздоровительных технологий

Национального университета обороны Украины имени Ивана Черняховского

\section{Особенности подготовки будущих специалистов физической подготовки и спорта к работе с военнослужащими с ограниченными физическими возможностями}

В статье рассмотрена проблема подготовки будущих спещиалистов физической подготовки и спорта к работе с военнослужащими с ограниченными физическими возможностями. Выяснено, что решающую роль для реабилитации военнослужащих $c$ особыми потребностями играет двигательная активность. Однако, анализ научнометодической литературы и военной практики показал, что вопросу их подготовки не уделено достаточного внимания.

Осуществлен анализ программы подготовки бакалавров по дисциплине "Физическая реабилитация $и$ адаптивное физическое воспитание", которая разработана 8 соответствии со стандартом высшего образования по специальности "Физическая культура и спорт" и учитывает психолого-педагогические различия в деятельности профессионала в области адаптивной физической культуры. Указанная программа состоит из трех блоков: теоретического, методического и практического и позволяет на должном уровне подготовить будущих специалистов физической подготовки и спорта к работе с военнослужащими с ограниченными физическими возможностями.

Ключевые слова: адаптивное физическое воспитание; будущие спечиалисть по физической подготовке и спорту; подготовка; ограниченные физические возможности; военнослужащие; нозологии.

\section{SUMMARY}

Nazarii Verbin,

Candidate of Pedagogical Sciences

Educational and Scientific Institute of Physical Culture and Sports and Health Technologies of the

National Defence University of Ukraine named after Ivan Cherniakhovskyi

Vadym Shemchuk,

Candidate of Pedagogical Sciences

Educational and Scientific Institute of Physical

Culture and Sports and Health Technologies of the

National Defence University of Ukraine named after Ivan Cherniakhovskyi

Anna Sainchuk,

Candidate of Sciences from physical wisdom and sports

Educational and Scientific Institute of Physical Culture and Sports and Health Technologies of the

National Defence University of Ukraine named after Ivan Cherniakhovskyi

Tetiana Tereshchenko,

Candidate of Medical Sciences

Educational and Scientific Institute of Physical

Culture and Sports and Health Technologies of the

National Defence University of Ukraine named after Ivan Cherniakhovskyi 


\section{Specific preparations of future specialists for physical preparations and sport before robotics with military servants with intermediate physical opportunities}

The article considers the problem of training future specialists in physical training and sports to work with servicemen with disabilities. It has been found that physical activity plays a crucial role in the rehabilitation of servicemen with special needs. However, the analysis of scientific and methodological literature and military practice showed that not enough attention was paid to the issue of their preparation.

The analysis of the bachelor's program in the discipline "Physical Rehabilitation and Adaptive Physical Education", which was developed in accordance with the standard of higher education in "Physical Culture and Sports" and takes into account psychological and pedagogical differences in the activities of professionals in adaptive physical culture. This program consists of three blocks: theoretical, methodological and practical and allows to properly prepare future specialists in physical training and sports to work with servicemen with disabilities.

Practical training of future specialists in physical training and sports is carried out during the solution of problematic practical tasks for assessment and analysis of health and physical development of persons of different nosological groups, development of motor activity programs based on the basic laws of physical development. qualities of adaptive physical education, the dependence of the development of physical abilities on motor modes and the stage of development of physical qualities. Also determine the amount of motor skills and testing during various nosologies, develop guidelines for adaptive physical education for people in this category.

Key words: adaptive physical education; future specialists in physical training and sports; preparation; limited physical capabilities; military; nosology. 